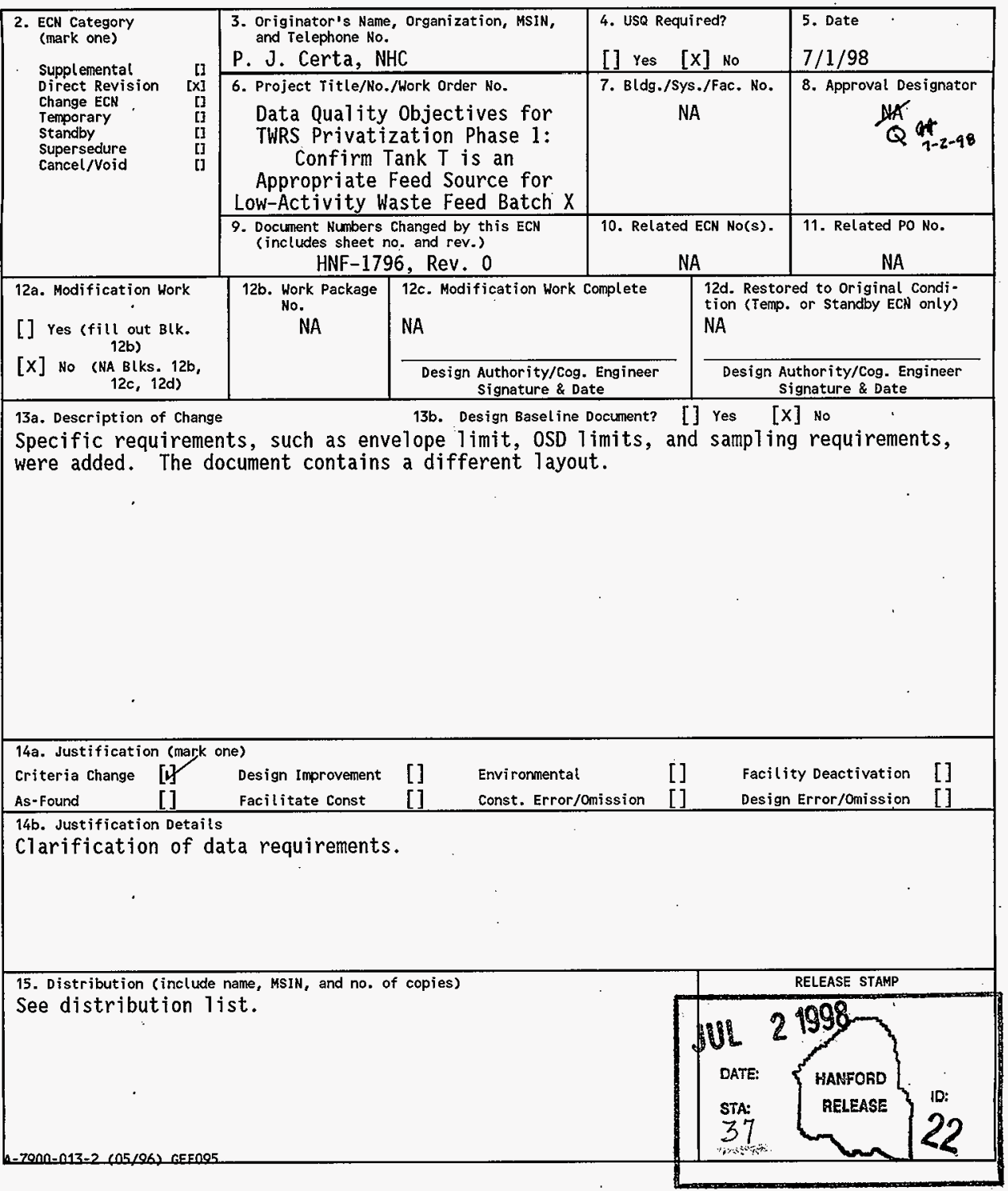




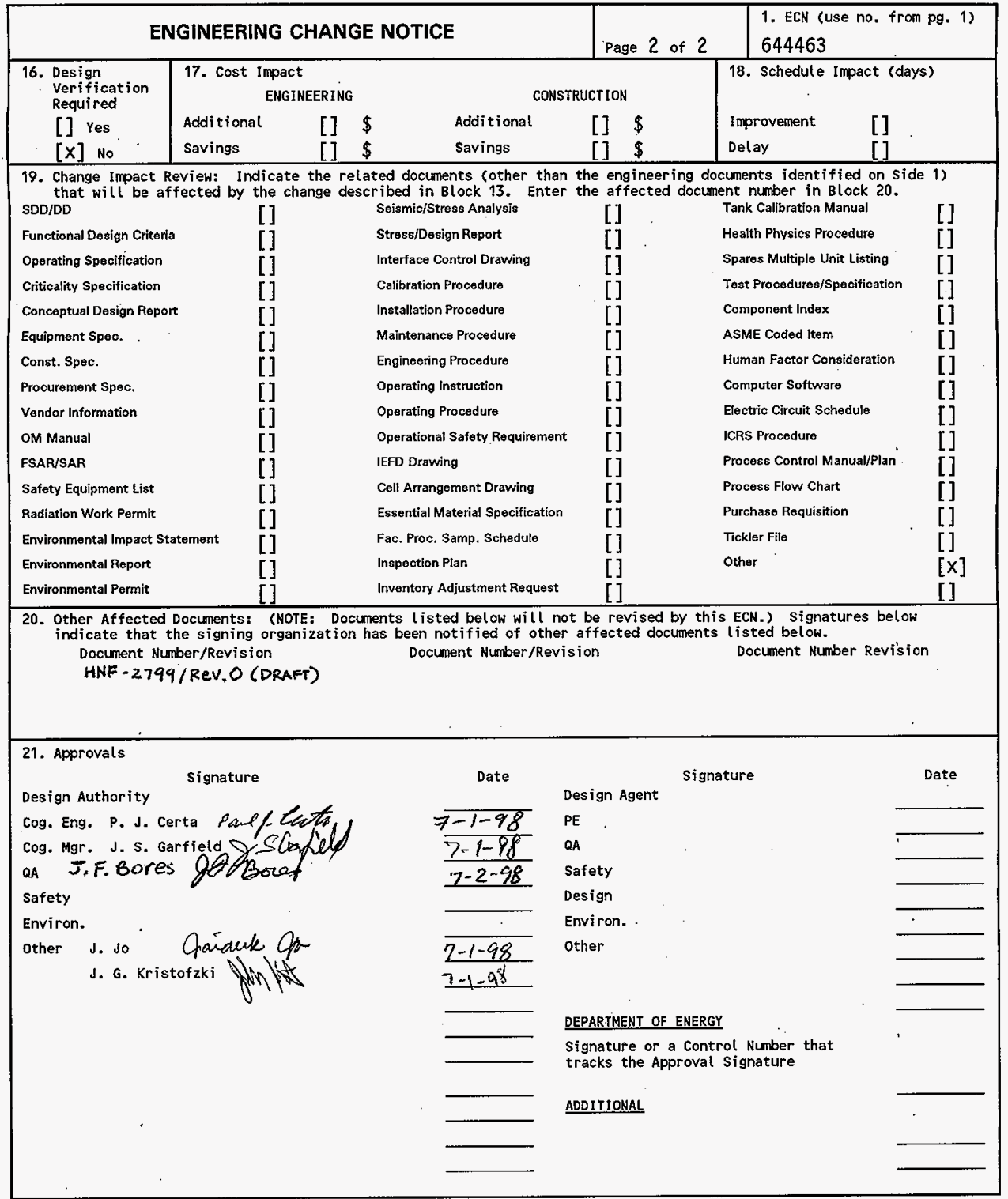




\title{
Data Quality Objectives for TWRS Privatization Phase 1: Confirm Tank $T$ is an Appropriate Feed Source for Low-Activity Waste Feed Batch $X$
}

\author{
P. J. Certa and J. Jo (LMHC) \\ Numatec Hanford Corporation, Richland, WA 99352 \\ U.S. Department of Energy Contract DE-AC06-96RL13200
}

\author{
EDT/ECN: 644463 \\ Org Code: $8 \mathrm{C} 451$ \\ UC: $721,4 \mathrm{C}-2000$ \\ B\&R Code: EW3130000 \\ Charge Code: D2D28 \\ Total Pages: $30 \mathrm{cw} 7-2-98$
}

Key Words: Data quality objectives, DQ0, low-activity waste, TWRS

Abstract: The Phase 1 privatization contracts require that the Project Hanford Management Contractor contractors, on behalf of the U.S. Department of Energy, Richland Operations Office, deliver the appropriate quantities of the proper composition of feed on schedule to the Privatization contractors. The type of feed needed, the amount of feed needed, and the overall timing of when feed is to be delivered to the Privatization contractor are specified by the contract. This document outlines the Data Quality objective process that will confirm the feed source(s) are appropriate for a specific batch before transfer is made to the feed staging tanks.

TRADEMARK DISCLÁIMER. Reference herein to any specific commercial product, process, or service by trade name, trademark, manufacturer, or otherwise, does not necessarily constitute or imply its endorsement, recommendation, or favoring by the United States Government or any agency thereof or its contractors or subcontractors.

Printed in the United States of America. To obtain copies of this document, contact: Document Control Services, P.0. Box 950, Mailstop H6-08, Richland WA 99352, Phone (509) 372-2420; Fax (509) 376-4989.
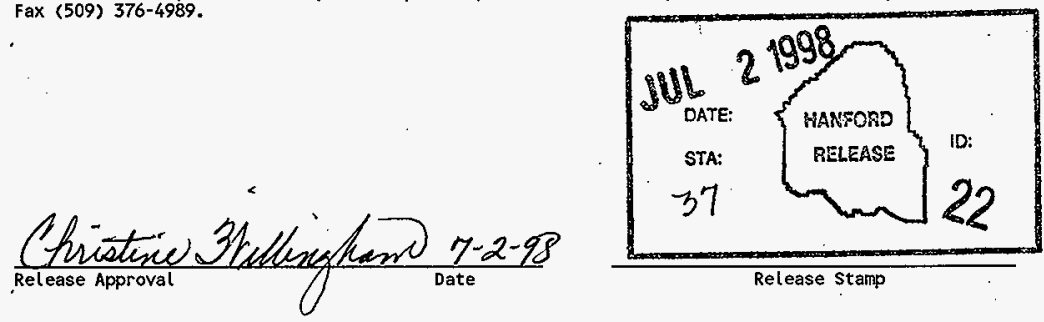
(2) Title

Data Quality Objectives for TWRS Privatization Phase 1: Confirm Tank $T$ is an Appropriate Feed Source for Low-Activity Waste Feed Batch $X$

(3) Revision

0

1 RS
(4) Description of Change - Replace, Add, and Delete Pages (7) Initial release $1 / 20 / 98$, EDT 622701.

7/1/98 Direct revision per $\mathrm{ECN}-644463$.
Authorized for Release

(5) Cog. Engr. (6) Cog. Mgr. Date

P. J. Certa J. S. Garfield

P. J. Certa

J. Scranfilgid 


\title{
DATA QUALITY OBJECTIVES FOR TWRS PRIVATIZATION PHASE 1: CONFIRM TANK T IS AN APPROPRIATE FEED SOURCE FOR LOW-ACTIVITY WASTE FEED BATCH $X$
}

June 1998

\author{
P. J. Certa
}

Numatec Hanford Corporation

Richland, Washington

J. Jo

Lockheed Martin Hanford Corporation

Richland, Washington

Prepared for

U.S. Department of Energy

Richland, Washington 
This page intentionally left blank. 


\section{CONTENTS}

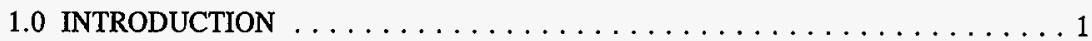

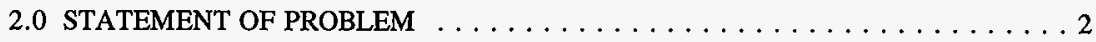

3.0 IDENTIFICATION OF DECISIONS $\ldots \ldots \ldots \ldots \ldots \ldots \ldots \ldots$ 3.1 DATA QUALITY OBJECTIVE DECISION LOGIC IMPLEMENTATION . . 3

4.0 INPUTS TO THE DECISION $\ldots \ldots \ldots \ldots \ldots \ldots \ldots \ldots \ldots \ldots$

4.1 DILUTION RATIO AND DILUENT COMPOSITION REQUIREMENTS $\ldots 77$

4.2 TRANSFER REQUIREMENTS $\ldots \ldots \ldots \ldots \ldots \ldots \ldots \ldots \ldots \ldots$

4.3 MIXING REQUIREMENTS . . . . . . . . . . . . . . . 8

4.4 ENVELOPE AND QUANTITY REQUIREMENTS . . . . . . . . . . 9

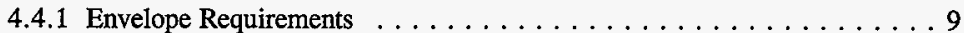

4.4 .2 Quantity Requirements . . . . . . . . . . . . . . . 12

4.5 MISCELLANEOUS INPUT $\ldots \ldots \ldots \ldots \ldots \ldots \ldots \ldots \ldots \ldots$

4.6 INFORMATION REQUIREMENT $\ldots \ldots \ldots \ldots \ldots \ldots \ldots \ldots$

5.0 DEFINE THE STUDY BOUNDARIES $\ldots \ldots \ldots \ldots \ldots \ldots \ldots \ldots \ldots$

6.0 DEVELOP A DECISION RULE $\ldots \ldots \ldots \ldots \ldots \ldots \ldots \ldots \ldots \ldots \ldots \ldots \ldots$

7.0 SPECIFY LIMITS ON DECISION ERROR . . . . . . . . . . . . . . . . 17

7.1 DILUTION RATIO AND DILUENT COMPOSITION REQUIREMENTS $\ldots 17$

7.2 TRANSFER REQUIREMENTS $\ldots \ldots \ldots \ldots \ldots \ldots \ldots \ldots \ldots \ldots \ldots$

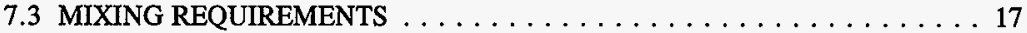

7.4 ENVELOPE AND QUANTITY REQUIREMENTS $\ldots \ldots \ldots \ldots \ldots \ldots . \ldots 17$

7.5 MISCELLANEOUS REQUIREMENTS $\ldots \ldots \ldots \ldots \ldots \ldots \ldots$

7.6 DATA REPORTING . . . . . . . . . . . . . . . . . . . 18

7.6.1 Laboratory Assessment and Report $\ldots \ldots \ldots \ldots \ldots \ldots \ldots$

7.6.2 Dissolution/Dilution Testing and Report . . . . . . . . . . . . . 19

7.6:3 Data Quality Objective Assessment and Report . . . . . . . . . . 19

8.0 OPTIMIZE THE DESIGN FOR OBTAINING DATA . . . . . . . . . . . . 19

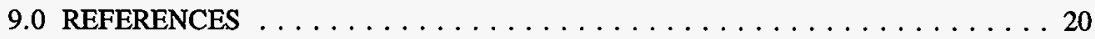




\section{LIST OF FIGURES}

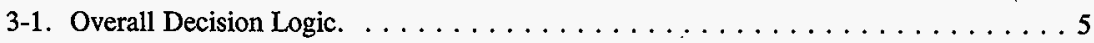

\section{LIST OF TABLES}

4-1. Feed Physical Properties $\ldots \ldots \ldots \ldots \ldots \ldots \ldots \ldots \ldots \ldots \ldots$

4-2. Low Activity Waste Feed Chemical Composition Limits . . . . . . . . . . 10

4-3. Low Activity Waste Feed Radionuclide Composition Limits . . . . . . . . . . 11

4-4. Operating Specifications from OSD-T-151-00007. $\ldots \ldots \ldots \ldots \ldots \ldots$

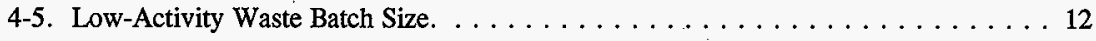

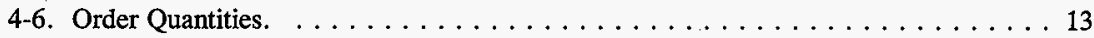

4-7. Required Analytes and Quality Control Parameters. . . . . . . . . . . . 14 


\section{LIST OF TERMS}

$\begin{array}{ll}\text { ANOVA } & \text { Analysis of variance } \\ \text { Bq/mole } & \text { Becquerel per mole } \\ \text { BTU/h } & \text { British thermal unit per hour } \\ \text { CI } & \text { Confidence interval } \\ \text { DOE } & \text { U.S. Department of Energy } \\ \text { DQO } & \text { Data quality objective } \\ \text { DST } & \text { Double-shell tank } \\ \text { ESP } & \text { Environmental Simulation Program } \\ \text { ICD } & \text { Interface control document } \\ \text { LAW } & \text { Low-activity waste } \\ M & \text { Molar } \\ \text { MT } & \text { Metric tons } \\ \text { PHMC } & \text { Project Hanford Management Contract } \\ \text { PMBS } & \text { Project master baseline schedule } \\ \text { PSDQO } & \text { Problem-Specific Data Quality Objectives } \\ \text { QA/QC } & \text { Quality assurance/quality control } \\ \text { RL } & \text { U.S. Department of Energy, Richland Operations Office } \\ \text { RTP } & \text { Readiness-to-Proceed } \\ \text { SpG } & \text { Specific Gravity } \\ \text { TIC } & \text { Total inorganic carbon } \\ \text { TOC } & \text { Total organic carbon } \\ \text { TRU } & \text { Transuranic } \\ \text { TSAP } & \text { Tank Sampling and Analysis Plan } \\ \text { TWRS } & \text { Tank Waste Remediation System } \\ \text { TWRSO\&UP } & \text { Tank Waste Remediation System Operation and Utilization Plan } \\ \text { UL } & \text { Upper limit } \\ \text { USQ } & \text { Unreviewed safety question } \\ \text { WHC } & \text { Westinghouse Hanford Company } \\ \text { WIT } & \text { Waste Disposal Integration Team } \\ \mu \text { Ci/L } & \text { Microcuries per liter } \\ & \end{array}$

${ }^{1}$ ESP is a trademark of OLI Systems, Inc. 
This page intentionally left blank 


\section{DATA QUALITY OBJECTIVES FOR TWRS PRIVATIZATION PHASE 1: CONFIRM TANK T IS AN APPROPRIATE FEED SOURCE FOR LOW-ACTIVITY WASTE FEED BATCH $x$}

\subsection{INTRODUCTION}

The Phase 1 privatization contracts require that the Project Hanford Management Contract (PHMC) contractors, on behalf of the U.S. Department of Energy, Richland Operations Office (RL), deliver the appropriate quantities of the proper composition of feed on schedule to the Privatization contractors (DOE-RL 1996). The type of feed needed, the amount of feed needed, and the overall timing of when feed is to be delivered to the Privatization contractor are specified by the contract. Additional requirements are imposed by the interface control document (ICD) for low-activity waste (LAW) feed (PHMC 1997a).

The Tank Waste Remediation System Operation and Utilization Plan (TWRSO\&UP) (Kirkbride et al. 1997) as updated by the Readiness-to-Proceed (RTP) deliverable (Payne et ai. 1998) establishes the baseline operating scenario for the delivery of feed to two Privatization contractors for the first twelve LAW batches. The project master baseline schedule (PMBS) and corresponding logic diagrams that will be used to implement the operating scenario have been developed and are currently being refined.

The baseline operating scenario in the TWRSO\&UP/RTP specifies which tanks will be used to provide feed for each specific feed batch, the operational activities needed to prepare and deliver each feed batch, and the timing of these activities. This operating scenario has considered such factors as the privatization contracts and ICD requirements, waste composition and chemistry, equipment availability, project schedules and funding, tank farm logistics and the availability of tank space.

The PMBS includes activities to reduce programmatic risk. The purpose of one of these activities, "Confirm Plans and Requirements," is to confirm the proper trade-offs (in the factors listed in the above paragraph) were made in developing the operating scenario for each and every feed batch and to verify there are no other reasons (in the equipment design, process control, safety, or permitting areas) to reject the baseline plans for the feed batch under. consideration. The "Confirm Plans and Requirements" activity will follow the Tank Waste Remediation System (TWRS) decision management process (WHC 1996). 


\section{Revision 1}

One of the inputs to the "Confirm Plans and Requirements" decision is to confirm that the proposed feed source(s) are appropriate for a batch in terms of composition, quantity, and transfer properties. This document outlines the Data Quality Objective (DQO) process that will confirm the feed source(s) are appropriate for a specific batch before transfer is made to the feed staging tanks. The DQO process will be accomplished according to the TWRS DQO process (Banning 1997) with some activities and/or steps modified to accommodate the Tank Waste Retrieval Division Project-specific requirements. This document will be revised as new information warrants.

\subsection{STATEMENT OF PROBLEM}

As part of the Waste Feed Delivery program, specific tanks, in a specific sequence, need to be staged for delivery of feed to the private contractor. The selection of the tank, or group of tanks is subject to the following criteria:

- The type of feed (chemical nature) and the amount of feed needed at a specific time by the private contractor.

- The physical composition of the waste feed to assure the waste can be removed and - transferred.

Before applying this DQO to determine if Tank $\mathrm{T}^{1}$ is appropriate for Batch $\mathrm{X}$, Tank $\mathrm{T}$ was selected by using the best-basis inventory and other factors documented in the TWRSO\&UP. This DQO focuses on the activities needed to confirm the waste in Tank T, which was previously selected, is appropriate in terms of composition, quantity, and ability to be transferred.

The basic problem is to confirm that the process streams from the retrieval and staging of a specific feed source tank $(T)$ have the desired chemical and physical properties to support the "Confirm Plans and Requirements" activity in the PMBS for the specific feed batch under consideration (Batch X).

l"Tank T" refers to the contents from one tank, multiple tanks, or portions of one or more tanks that may be used to prepare a given feed batch. 


\subsection{IDENTIFICATION OF DECISIONS}

To determine if a specific batch of waste in a specific tank is an appropriate feed, the primary question of "Is the waste in Tank $\mathrm{T}$ appropriate for use as source material for the makeup of Low-Activity Waste Feed Batch X?" must be answered. follows:

The specific sub-questions that must be answered in order to make the decision are as

- Will the waste meet Envelope Limits after staging (including dissolution), blending, and/or shimming?

- Will the quantity of retrievable sodium satisfy the quantity requirements?

- Does the waste have acceptable transfer properties?

The overall decision logic for implementing this DQO is shown schematically in Figure 3-1 and briefly discussed in section 3.1 .

\subsection{DATA QUALITY OBJECTIVE DECISION LOGIC IMPLEMENTATION}

To answer the questions listed above, the elements of the decision rule (Section 6.0) will be applied to the different scenarios developed by the Tank Waste Retrieval Division for each specific Tank $\mathrm{T}$ and Batch $\mathrm{X}$ combination. This provides the flexibility to account for unique factors that may only become apparent during the application of the DQO.

The first step in addressing the elements in the decision rule is for the Tank Waste Retrieval Division to translate its operating scenario into a series of process steps ${ }^{1}$ (essentially a process flowsheet) that clearly defines the waste ${ }^{2}$ to which each element of the decision rule applies. Alternatives to the baseline operating scenario may also be addressed.

${ }^{1}$ For example only, an operating scenario used to create Batch 1 from 241-AN-105 may be as follows: (a) degas the tank; (b) decant and transfer half of the supernate from 241-AN-105 into 241-AP-102 and the other half into 241-AP-104 using a dilution ratio of $\mathrm{x}: 1$ and a diluent of $2 \mathrm{M} \mathrm{NaOH}$; (c) add y $\mathrm{mL}$ of dilution water to the salt slurry remaining in . 241-AN-105; (d) mix to dissolve soluble salts; (e) allow undissolved solids to settle; (f) decant and transfer half of the clarified liquid in 241-AN-105 into 241-AP-102 and the other half into 241-AP-104; (g) mix the waste in 241-AP-102 and mix the waste in 241-AP-104.

${ }^{2}$ For example only, the decision rule for second transfer ( $f$ in footnote 2 , above) will need to apply to that portion of the salt slurry that dissolves under the stated dilution conditions. 
The second step is to apply the decision rule (Section 6.1) to each group of operating scenario activities that constitute a source of waste feed going to the waste feed staging tanks.

The third step is to determine if the data needed to address each element can be supplied by or approximated with existing (Best-Basis Inventory) or new characterization data on the waste, statistical evaluations, mathematical or process models such as Environmental Simulation Program (ESP ${ }^{1}$ ), or by process testing on existing or new samples including dissolution/dilution testing.

If the existing data are insufficient to complete a full evaluation, additional data must be obtained from Tank $T$. The missing information needs to be identified and formally documented. Unless sufficient archived samples can be found, Tank $T$ waste must be sampled and analyzed. Once these data are obtained, they shall be compiled into the existing database for Tank $T$ and a reevaluation of the data must be made. If all the limits are satisfied by the Tank T.waste, Tank $\mathrm{T}$ waste is appropriate for Feed Batch $\mathrm{X}$.

If all the limits are not satisfied as stated in sections 4.0 and 7.0 , then activities including blending and/or shimming could be attempted to make Tank $\mathrm{T}$ appropriate for feed Batch $\mathrm{X}$. If this fails and all the limits are not satisfied by the Tank $\mathbf{T}$ waste data but the limits in PHMC's plans and requirements (ICD, TWRSO\&UP) can be changed such that new limits can be satisfied, than Tank $T$ waste is appropriate for Feed Batch $X$. If all the limits are not satisfied by the Tank T waste data and the limits in PHMC's plans and requirements cannot be changed to satisfy all the limits, RL could negotiate new feed specification or other contract terms with the private contractors. If all of these fail, then Tank $\mathrm{T}$ waste is not acceptable for Batch X.

${ }^{1}$ ESP is a trademark of OLI Systems, Inc. 
Figure 3-1. Overall Decision Logic. (Sheet 1 of 2)

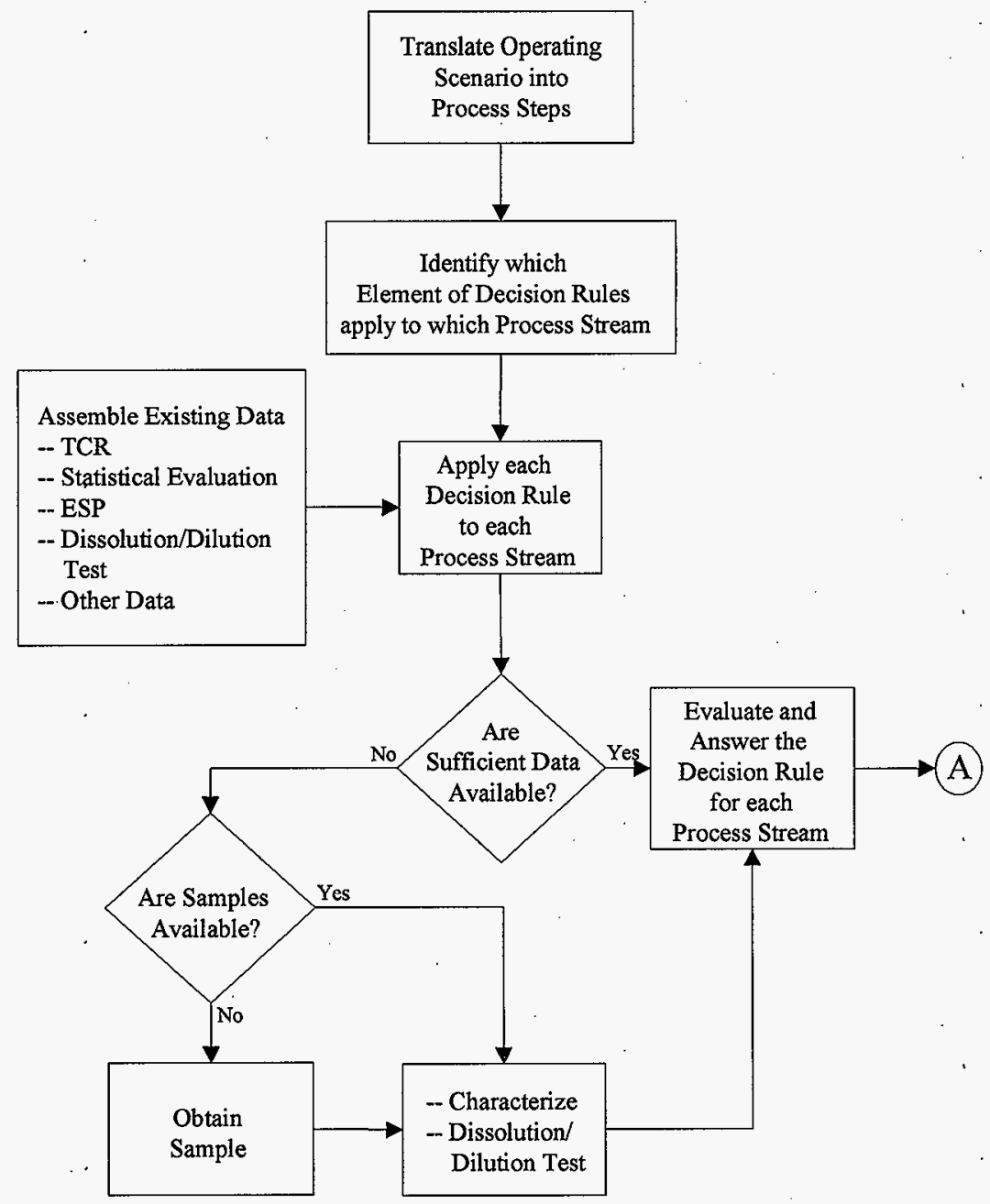


HNF-1796

Figure 3-1. Overall Decision Logic. (Sheet 2 of 2)

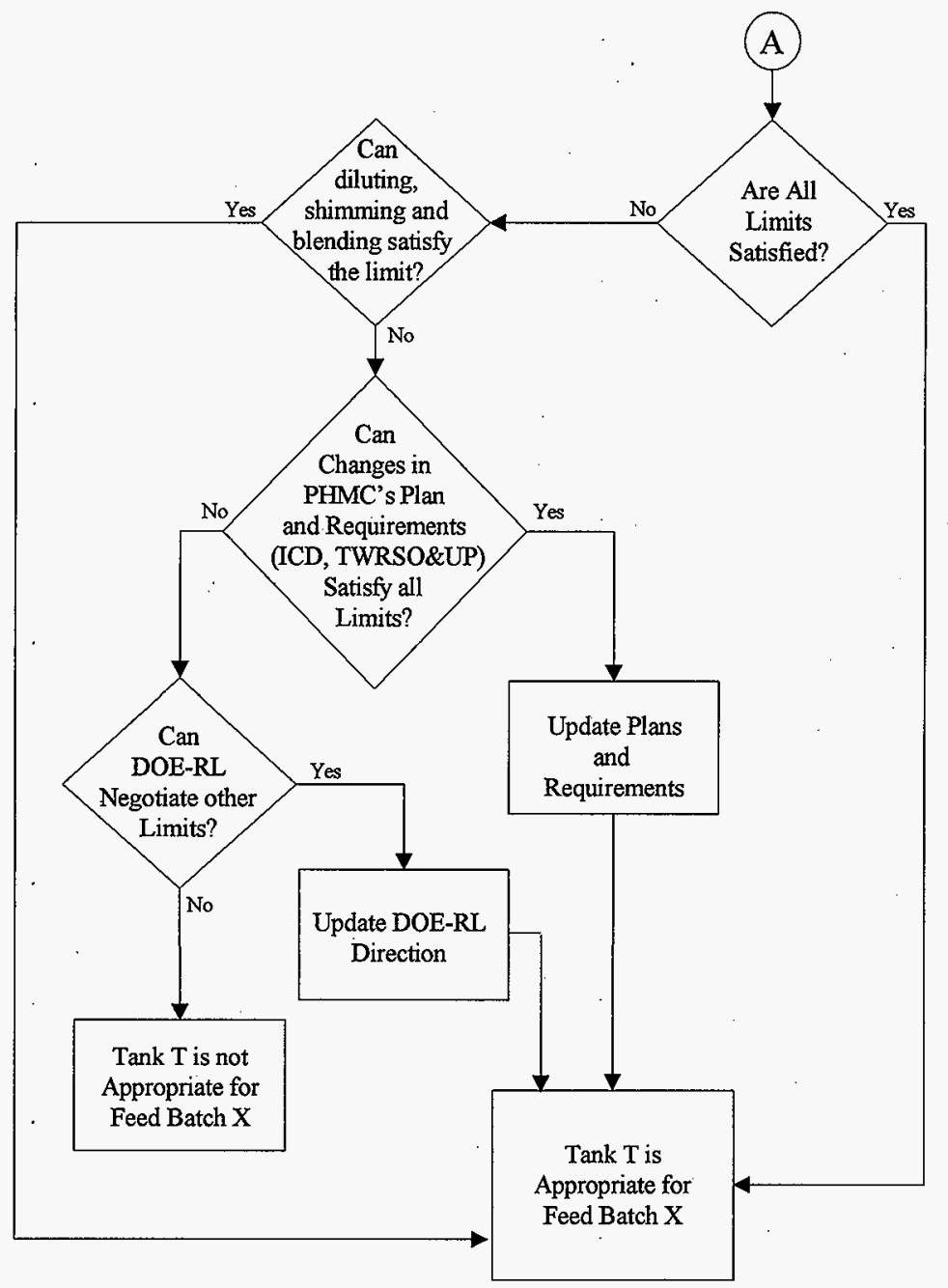




\subsection{INPUTS TO THE DECISION}

Before confirming a tank is appropriate for staging as batch $\mathrm{X}$, activities occur using dissolution/dilution testing, best-basis inventory estimates, and other factors to determine whether the tank will be appropriate for delivering the right type, composition, and quantity of feed to the contractors on time. The decision as to whether or not a tank is appropriate for staging is divided into several major categories. The data inputs for these categories come from two major sources; chemical analyses of the waste and a dissolution/dilution test of the waste. The other existing information may also be used. The inputs for these categories are listed in the following sections.

\subsection{DILUTION RATIO AND DILUENT COMPOSITION REQUIREMENTS}

The desired dilution ratio and diluent composition for each waste transfer will be determined. The range of dilution ratios and the diluent composition to be evaluated will be estimated from existing composition and thermodynamic equilibrium calculations (test results from similar waste may also be used) and may be bounded by practical considerations such as tank volume limitations or by the minimum sodium concentration allowed by the feed specifications.

The requirements listed below are addressed by performing a dissolution/dilution test per test plan for Tank $\mathbf{T}$.

- Determine the minimum dilution ratio which satisfies all transfer system requirements except for gibbsite formation (at temperature ranges $25^{\circ} \mathrm{C}-65^{\circ} \mathrm{C}$ )

- Determine the maximum dilution ratio, beyond which gibbsite will form (at temperature ranges $25^{\circ} \mathrm{C}-65^{\circ} \mathrm{C}$ ) or based on allowable tank storage space considerations

- Select a desired dilution ratio slightly above the minimum ratio for the desired diluent.

\subsection{TRANSFER REQUIREMENTS}

For each waste transfer at the desired dilution ratio and diluent composition, verify that all of the transfer requirements are satisfied.

The transfer requirements are listed below: 


\section{Revision 1}

- Confirm that the retrieved waste (including dilution water or caustic) will remain below saturation in major Na salts during the transfer to the staging tank (Kirkbride et al. 1997). If the saturation point is not available in Kirkbride et al. (1997), establish the saturation point.

- Confirm that the retrieved waste (including dilution water or caustic) will remain at or below the physical property limits identified in Table 4-1 during the transfer to the staging tank. These values were used by Galbraith et al. (1996) in analyzing the capability of the proposed transfer routes for staging of feed.

Table 4-1. Feed Physical Properties.

\begin{tabular}{|c|c|}
\hline Parameter & Maximum limit \\
\hline Viscosity (cP) & 10 \\
\hline Specific gravity & 1.5 \\
\hline Volume percent solids (\%) & 30 \\
\hline
\end{tabular}

- Confirm as per Kirkbride et al. (1997) that the dilution ratio, diluent composition, and waste composition are balanced so gibbsite or high viscosity slurries do not precipitate. If the data are not available in Kirkbride et al. (1997), establish the dilution ratio, diluent composition, and waste composition needed to prevent precipitation of gibbsite or high viscosity slurries.

\subsection{MIXING REQUIREMENTS}

The need for mixing depends upon the form of the tank waste contents and the form the tank waste contents must be in to make up a specific batch. The requirements listed below confirm (1) the baseline retrieval equipment is consistent with the operating scenario and (2) solids in the source tank behave as expected with respect to dissolution and solid/liquid separation via in-tank settling.

- Determine the portion of the solids which are soluble and the amount of time to dissolve the soluble solids. Confirm the diluted waste after final decant contains . less than or equal to $0.5 \mathrm{wt} \%$ solid as stated in the operating scenario (Kirkbride et al. 1997).

- Determine the undissolved solids settle time and confirm settling time is less than 30 days as stated in the operating scenario (Kirkbride et al. 1997). 
- Confirm that the baseline retrieval equipment, used to mobilize and transfer the waste, is consistent with the operating scenario. If a significant quantity of solids require dissolution, verify the baseline retrieval equipment includes provisions for mixing the waste.

The inputs here should not be confused with the inputs required for the design and installation of a particular mixer pump to be placed in feed source tank. Those inputs will be covered in the detailed equipment evaluation that will be documented in the Waste Feed Delivery Technical Basis, Volume III, Waste Feed Delivery Process Design Concept, per Papp (1998).

\subsection{ENVELOPE AND QUANTITY REQUIREMENTS}

Verify that the requirements in Sections 4.4.1 (Envelope Requirements) and 4.4.2 (Quantity Requirements) are satisfied.

\subsubsection{Envelope Requirements}

Envelope requirements are shown in Tables 4-2 and 4-3 for LAW. These requirements. ${ }^{1}$ are taken from Specification 7 in Section C.6 of the contracts (DOE-RL 1996) and Section 3.3.2 of the ICD (PHMC 1997a). Envelope limits are intended to apply to the feed that is actually delivered to the Privatization contractors (i.e., transferred from the staging tanks 241-AP-102 and -104 to the private contractor's feed tanks 241-AP-106 and -108), which is not always the same as the composition of the waste residing in the source tank.

- Concentration limits for the chemical and radionuclide content of the feed.

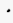

- Concentration limit for the sodium concentration of the feed: $3 \mathrm{M} \leq[\mathrm{Na}] \leq 14 \mathrm{M}$

- Insoluble solids fraction limit: $\leq 5$ volume percent

- Operating Specifications from OSD-T-151-00007, Rev H-16 (e.g. relating to corrosion and heat generation rate) (PHMC 1997b), Table 4-4

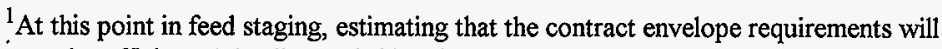
likely be met is sufficient. Blending and shimming options provide the flexibility at later stages, if an analyte approaches or falls outside of the maximum or minimum allowable limit. 
Table 4-2. Low Activity Waste Feed Chemical Composition Limits.

\begin{tabular}{|c|c|c|c|}
\hline Analyte & $\begin{array}{c}\text { Envelope } \mathrm{A}^{1} \\
\text { mole/mole } \mathrm{Na}\end{array}$ & $\begin{array}{c}\text { Envelope } \mathrm{B}^{1} \\
\text { mole/mole Na }\end{array}$ & $\begin{array}{c}\text { Envelope } \mathrm{C}^{1} \\
\text { mole/mole } \mathrm{Na}\end{array}$ \\
\hline Al & $1.9 \mathrm{E}-01$ & $1.9 \mathrm{E}-01$ & $1.9 \mathrm{E}-01$ \\
\hline $\mathrm{Ba}$ & $1.0 \mathrm{E}-04$ & $1.0 \mathrm{E}-04$ & $1.0 \mathrm{E}-04$ \\
\hline $\mathrm{Ca}$ & $4.0 \mathrm{E}-02$ & $4.0 \mathrm{E}-02$ & $4.0 \mathrm{E}-02$ \\
\hline $\mathrm{Cd}$ & $4.0 \mathrm{E}-03$ & $4.0 \mathrm{E}-03$ & $4.0 \mathrm{E}-03$ \\
\hline $\mathrm{Cl}$ & $3.7 \mathrm{E}-02$ & $8.9 \mathrm{E}-02$ & $3.7 \mathrm{E}-02$ \\
\hline $\mathrm{Cr}$ & $6.9 \mathrm{E}-03$ & $2.0 \mathrm{E}-02$ & $6.9 \mathrm{E}-03$ \\
\hline $\mathrm{F}$ & $9.1 \mathrm{E}-02$ & $2.0 \mathrm{E}-01$ & 9.1 E-02 \\
\hline $\mathrm{Fe}$ & $1.0 \mathrm{E}-02$ & $1.0 \mathrm{E}-02$ & $1.0 \mathrm{E}-02$ \\
\hline $\mathrm{Hg}$ & $1.4 \mathrm{E}-05$ & $1.4 \mathrm{E}-05$ & $1.4 \mathrm{E}-05$ \\
\hline $\mathrm{K}$ & $1.8 \mathrm{E}-01$ & $1.8 \mathrm{E}-01$ & $1.8 \mathrm{E}-01$ \\
\hline $\mathrm{La}$ & 8.3 E-05 & 8.3 E-05 & 8.3 E-05 \\
\hline $\mathrm{Na}$ & $1.0 \mathrm{E}-00$ & $1.0 \mathrm{E}-00$ & $1.0 \mathrm{E}-00$ \\
\hline $\mathrm{Ni}$ & $3.0 \mathrm{E}-03$ & 3.0 E-03 & $3.0 \mathrm{E}-03$ \\
\hline $\mathrm{NO}_{2}^{-}$ & $3.8 \mathrm{E}-01$ & $3.8 \mathrm{E}-01$ & $3.8 \mathrm{E}-01$ \\
\hline $\mathrm{NO}_{3}^{-}$ & $8.0 \mathrm{E}-01$ & 8.0 E-01 & $8.0 \mathrm{E}-01$ \\
\hline $\mathrm{OH}^{-}$ & 7.0 E-01 & $7.0 \mathrm{E}-01$ & $7.0 \mathrm{E}-01$ \\
\hline $\mathrm{Pb}$ & $6.8 \mathrm{E}-04$ & $6.8 \mathrm{E}-04$ & $6.8 \mathrm{E}-04$ \\
\hline $\mathrm{PO}_{4}^{-3}$ & $3.8 \mathrm{E}-02$ & $1.3 \mathrm{E}-01$ & $3.8 \mathrm{E}-02$ \\
\hline $\mathrm{SO}_{4}^{-2}$ & 9.7 E-03 & $7.0 \mathrm{E}-02$ & $2.0 \mathrm{E}-02$ \\
\hline TIC & $3.0 \mathrm{E}-01$ & 3.0 E-01 & $3.0 \mathrm{E}-01$ \\
\hline TOC & $6.0 \mathrm{E}-02$ & 6.0 E-02 & 5.0 E-01 \\
\hline $\mathrm{U}$ & $1.2 \mathrm{E}-03$ & $1.2 \mathrm{E}-03$ & $1.2 \mathrm{E}-03$ \\
\hline
\end{tabular}

${ }^{1}$ Maximum ratio, mole of analyte to mole of sodium. 
Table 4-3. Low Activity Waste Feed Radionuclide Composition Limits.

\begin{tabular}{|c|c|c|c|}
\hline Analyte & $\mathrm{Bq} / \mathrm{mole} \mathrm{Na}^{1}$ & $\mathrm{~Bq} / \mathrm{mole} \mathrm{Na}^{1}$ & $\mathrm{~Bq} / \mathrm{mole} \mathrm{Na}^{1}$ \\
\hline $\mathrm{TRU}^{2}$ & $4.8 \mathrm{E}+05$ & $4.80 \mathrm{E}+05$ & $3.0 \mathrm{E}+06$ \\
\hline${ }^{137} \mathrm{Cs}$ & $4.3 \mathrm{E}+09$ & $6.0 \mathrm{E}+10$ & $4.3 \mathrm{E}+09$ \\
\hline${ }^{90} \mathrm{Sr}$ & $4.4 \mathrm{E}+07$ & $4.4 \mathrm{E}+07$ & $8.0 \mathrm{E}+08$ \\
\hline${ }^{99} \mathrm{Tc}$ & $7.1 \mathrm{E}+06$ & $7.1 \mathrm{E}+06$ & $7.1 \mathrm{E}+06$ \\
\hline
\end{tabular}

${ }^{\mathrm{I}}$ Maximum ratio, $\mathrm{Bq}$ of radionuclide to mole of sodium.

${ }^{2}$ Radionuclides contributing to TRU are those alpha-emitting transuranic radionuclides with half-lives greater than 5 years $\left({ }^{236} \mathrm{~Np},{ }^{237} \mathrm{~Np},{ }^{238} \mathrm{Pu},{ }^{239} \mathrm{Pu},{ }^{240} \mathrm{Pu}\right.$, ${ }^{242} \mathrm{Pu}{ }^{244} \mathrm{Pu},{ }^{241} \mathrm{Am},{ }^{242} \mathrm{Am},{ }^{243} \mathrm{Am},{ }^{243} \mathrm{Cm},{ }^{244} \mathrm{Cm},{ }^{245} \mathrm{Cm},{ }^{246} \mathrm{Cm}$, and ${ }^{247} \mathrm{Cm}$.

Table 4-4. Operating Specifications from OSD-T-151-00007.

\begin{tabular}{|c|c|}
\hline $\begin{array}{c}\mathrm{NO}_{3}^{-} \text {Conc. } \\
\text { (molar) }\end{array}$ & $\begin{array}{l}\mathrm{OH}^{-} \text {and } \mathrm{NO}_{2}^{-} \text {Limits } \\
\text { (molar) }\end{array}$ \\
\hline$\leq 1.0 \mathrm{M}$ & $\begin{array}{c}0.01<\left[\mathrm{OH}^{-}\right]<5.0 \mathrm{M}\left(8.0 \mathrm{M} \text { if } \mathrm{T}<167^{\circ} \mathrm{F}\right) \\
0.011<\left[\mathrm{NO}_{2}^{-}\right]<5.5 \mathrm{M} \\
{\left[\mathrm{NO}_{3}^{-}\right] /\left(\left[\mathrm{OH}^{-}\right]+\left[\mathrm{NO}_{2}^{-}\right]\right)<2.5}\end{array}$ \\
\hline 1.0 to $3.0 \mathrm{M}$ & $\begin{array}{c}0.1^{*}\left[\mathrm{NO}_{3}^{-}\right]<\left[\mathrm{OH}^{-}\right]<10 \mathrm{M} \\
{\left[\mathrm{NO}_{2}^{-}\right]+\left[\mathrm{OH}^{-}\right] \geq 0.4^{*}\left[\mathrm{NO}_{3}^{-}\right]}\end{array}$ \\
\hline 3.0 to $5.5 \mathrm{M}$ & $\begin{array}{c}0.3<\left[\mathrm{OH}^{-}\right]<10 \mathrm{M} \\
{\left[\mathrm{NO}_{2}^{-}\right]+\left[\mathrm{OH}_{-}\right] \geq 1.2 \mathrm{M}}\end{array}$ \\
\hline \multicolumn{2}{|c|}{ Heat Generation Rate } \\
\hline Variable & Specification Limit \\
\hline Max, Heat Generation Rate & $70,000 \mathrm{BTU} / \mathrm{hr}$ \\
\hline Max. Cs-137 Concentration & $5.74 \times 10^{5} \mu \mathrm{Ci} / \mathrm{L}$ \\
\hline Max. Sr-90 Concentration & $4.04 \times 10^{5} \mu \mathrm{Ci} / \mathrm{L}$ \\
\hline
\end{tabular}




\subsubsection{Quantity Requirements}

These requirements are found in Section H.9 of the contracts (DOE-RL 1996), Section 3.3 of the ICD (PHMC 1997a), and the TWRSO\&UP (Kirkbride et al. 1997) and RTP (Payne et al. 1998). Quantity limits are intended to apply to the feed that is actually delivered to the Privatization contractors, which is not always the same as the quantity of the waste residing in the source tank. The required mass of sodium in the LAW Feed to be delivered to the LAW Privatization contractors is stated in Table 4-5.

Table 4-5. Low-Activity Waste Batch Size.

\begin{tabular}{|c|c|c|c|}
\hline Batch(es) & Envelope & $\begin{array}{c}\text { Required mass } \\
\text { of sodium (MT) }\end{array}$ & $\begin{array}{c}\text { Target mass of } \\
\text { sodium (MT) }\end{array}$ \\
\hline 1 & A & $\geq 500$ & $500-600$ \\
\hline 2 to $\mathrm{i}^{1}$ & A & $\geq 100$ & $250-600$ \\
\hline $\mathrm{i}+1$ & B & $\geq 100$ & $100-250$ \\
\hline $\mathrm{i}+2$ & $\mathrm{C}$ & $\geq 100$ & $100-600$ \\
\hline $\mathrm{i}+3 \ldots \mathrm{j}^{2}$ & $\mathrm{C}$ & $\geq 100$ & $250-600$ \\
\hline $\mathrm{j}+1 \ldots \mathrm{k}^{2}$ & A & $\geq 100$ & $250-600$ \\
\hline $\mathrm{k}+1 \ldots \mathrm{m}^{2}$ & B & $\geq 100$ & $100-250$ \\
\hline
\end{tabular}

1 " $\mathrm{i}$ " is chosen so that the minimum order quantify of Envelope $\mathrm{A}$ is reached during batch " $\mathrm{I}$ "

${ }^{2} \mathrm{j}$ ", " $k$ ", and " $\mathrm{m}$ " are chosen so that delivered feed is consistent with -minimum and maximum order quantities, available feed stock and the feed staging operating scenario.

The minimum and maximum order quantities of LAW feed to be delivered to each LAW private contractor are found in Section 3.3 of the ICD (PHMC 1997a) and in Table 4-6. 
Table 4-6. Order Quantities.

\begin{tabular}{|c|c|c|}
\hline Envelope & $\begin{array}{c}\text { Minimum mass of sodium } \\
\text { per contractor (MT) }\end{array}$ & $\begin{array}{c}\text { Maximum mass of sodium } \\
\text { per contractor (MT) }\end{array}$ \\
\hline A & 2,600 & 4,900 \\
\hline B & 100 & 1,000 \\
\hline C & 100 & 2,400 \\
\hline A+B +C & $n / a$ & 5,100 \\
\hline
\end{tabular}

\subsection{MISCELLANEOUS INPUT}

In addition to the inputs described in Sections 4.1 through 4.4 the following information is needed. For each miscellaneous input listed in this section, determine which of these inputs apply to the specific tank waste being considered for specific batch and verify each applicable input is addressed.

- The physical form and quantity of the tank contents (crust, supernate, settled solids, salt slurry, metal oxide sludge) should be included in the laboratory report. This is used to confirm that the baseline retrieval equipment is consistent with the operating scenario.

- Estimated composition of heel from the prior batch remaining in staging tanks, if

- this heel will significantly influence the composition of staging tank waste (this will be provided from the computer simulation that modeled the operating scenario in the TWRSO\&UP or from previous laboratory analysis).

- Amounts of chemicals to be added for shimming the waste in the staging tanks to meet the requirements in Sections 4.1 through 4.4 , if any.

\subsection{INFORMATION REQUIREMENT}

Table 4-7 shows the analytes that require analyses, suggested analytical methods, and the quality control requirements to be used to collect the data for making the decisions in Section 4.0. The transuranic (TRU) elements and total alpha are required to determine the total transuranic radionuclides in the waste so a comparison can be made with the envelope limit for TRU (see Table 4-3). For purposes of this DQO, total alpha will be used as a conservative indicator of TRU content. Isotopic distribution will be required if total alpha is greater than 80 percent of the TRU envelope limit. 
Table 4-7. Required Analytes and Quality Control Parameters. (2 Sheets)

\begin{tabular}{|c|c|c|c|c|}
\hline \multirow{2}{*}{$\begin{array}{l}\text { Analytes } \\
\text { measured in } \\
\text { liquid }\end{array}$} & \multirow{2}{*}{$\begin{array}{l}\text { Analytical } \\
\text { technique }\end{array}$} & \multicolumn{3}{|c|}{ Quality control acceptance criteria } \\
\hline & & $\begin{array}{c}\text { LCS } \\
\text { \%ecovery } 1\end{array}$ & $\begin{array}{c}\text { Spike } \\
\text { \%Recovery }\end{array}$ & $\begin{array}{c}\text { Duplicate } \\
\text { RPD }^{3}\end{array}$ \\
\hline $\begin{array}{l}\mathrm{Al}, \mathrm{Ba}, \mathrm{Ca}, \mathrm{Cd}, \mathrm{Cr} \\
\mathrm{Fe}, \mathrm{K}, \mathrm{La}, \mathrm{Ni}, \mathrm{Pb}, \mathrm{U}\end{array}$ & ICP/AES ${ }^{7}$ & $80-120 \%$ & $75-125 \%$ & $\leq 20 \%$ \\
\hline $\begin{array}{l}\mathrm{NO}_{2}, \mathrm{NO}_{3}, \mathrm{PO}_{4}, \\
\mathrm{SO}_{4}, \mathrm{~F}, \mathrm{Cl}\end{array}$ & Ion Chromatography ${ }^{7}$ & $80-120 \%$ & $75-125 \%$ & $\leq 20 \%$ \\
\hline${ }^{99} \mathrm{Tc}$ & $\begin{array}{l}\text { ICP/MS and isotopic } \\
\text { specific separation/ } \\
\text { AEA }^{7}\end{array}$ & $80-120 \%$ & $70-130 \%$ & $\leq 20 \%$ \\
\hline $\mathrm{Na}$ & $\mathrm{ICP} / \mathrm{AES}^{7,6}$ & $80-120 \%$ & $75-125 \%$ & $\leq 5 \%$ \\
\hline $\mathrm{Hg}$ & CVAA $^{7,6}$ & $80-120 \%$ & $75-125 \%$ & $\leq 20 \%$ \\
\hline $\mathrm{OH}-$ & $\begin{array}{l}\text { Potentiometric } \\
\text { titration }\end{array}$ & $80-120 \%$ & N/A & $\leq 20 \%$ \\
\hline TIC & $\begin{array}{l}\text { persulfate and } \\
\text { combustion furnace }\end{array}$ & $80-120 \%$ & $75-125 \%$ & $\leq 20 \%$ \\
\hline TOC & $\begin{array}{l}\text { silver catalyzed } \\
\text { persulfate and } \\
\text { combustion furnace }^{7}\end{array}$ & $80-120 \%$ & $75-125 \%$ & $\leq 20 \%$ \\
\hline Density/SpG & & N/A & N/A & N/A \\
\hline Volume \% solids & gravimetric & $80-120 \%$ & N/A & $\leq 30 \%$ \\
\hline${ }^{90} \mathrm{Sr}$ & $\begin{array}{l}\text { isotopic specific } \\
\text { separation/beta count }\end{array}$ & $75-125 \%$ & N/A ${ }^{4}$ & $\leq 20 \%$ \\
\hline${ }^{237} \mathrm{~Np}$ & ICP/MS & $90-110 \%$ & $75-125 \%$ & $\leq 20 \%$ \\
\hline $\begin{array}{c}238 / 239 / \\
240 / 241 / 242 \mathrm{Pu}\end{array}$ & ICP/MS & $80-120 \%$ & $70-130 \%$ & $\leq 20 \%$ \\
\hline${ }^{241} \mathrm{Am}$ & separation/AEA & $80-120 \%$ & N/A ${ }^{4}$ & $\leq 20 \%$ \\
\hline $243+244 \mathrm{Cm}$ & separation/AEA & $\mathrm{NP}$ & $N / A^{4}$ & $\leq 20 \%$ \\
\hline${ }^{243} \mathrm{Am}$ & ICP/MS & $90-110 \%$ & $75-125 \%$ & $\leq 20 \%$ \\
\hline${ }^{137} \mathrm{Cs}$ & GEA & NP & $N / A^{5}$ & $\leq 20 \%$ \\
\hline Total Alpha & proportional counter & $70-130 \%$ & $70-130 \%$ & $\leq 20 \%$ \\
\hline
\end{tabular}




\section{Revision 1}

Table 4-7. Required Analytes and Quality Control Parameters. (2 Sheets)

AEA = Alpha energy analysis

CVAA $=$ cold vapor atomic absorption

GEA = gamma emission analysis

ICP/AES = Inductively coupled plasma/atomic emission spectroscopy

ICP/MS $=I C P /$ mass spectrometry

N/A $=$ Not applicable

$\mathrm{NP}=$ Not performed

TOC $=$ total organic carbon

TIC $=$ total inorganic carbon

${ }^{1}$ LCS = Laboratory Control Standard. This standard is carried through the entire method. The accuracy of a method is usually expressed as the percent recovery of the LCS. The LCS is a matrix with known concentration of analytes processed with each preparation and analyses batch. It is expressed as percent recovery; i.e., the amount measured, divided by the known concentration, times 100 .

${ }^{2}$ For some methods, the sample accuracy is expressed as the percent recovery of a matrix spike (MS) sample. It is expressed as percent recovery; i.e., the amount measured, less the amount in the sample, divided by the spike added, times 100 . One matrix spike is performed/analytical batch samples are batched with similar matrices.

${ }^{3}$ RPD $=$ Relative Percent Difference between the sample and duplicate results. Duplicates will be taken through preparation and analysis. Instrument analysis duplicates cannot be substituted except GEA which requires no preparation. Sample precision is estimated by analyzing duplicates. Acceptable sample precision is usually $<20$. percent RPD if the sample result is at least 10 times the instrument detection limit.

RPD $=(\mid$ Result 1 - Result $2 \mid$ /average result $) \times 100$.

${ }^{4} \mathrm{MS}$ analyses are not required for this method because a tracer is used to correct for analyte loss during sample preparation and analysis. The result generated using the tracer accounts for an inaccuracy of the method on the matrix. The reported results reflect this correction.

${ }^{5}$ The measurement is a direct reading of the energy and the analysis is not affected by the sample matrix; therefore, an MS is not required.

${ }^{6}$ All samples must be digested using the appropriate method before metals analyses.

${ }^{7}$ This method or other compatible method should be used. 


\subsection{DEFINE THE STUDY BOUNDARIES}

The spatial boundaries are the contents of Tank $T$.

The temporal boundaries are between the time Tank $\mathrm{T}$ has been selected as a candidate for Batch $\mathrm{X}$ and the transfer of Tank $\mathrm{T}$ waste to the intermediate waste feed staging tanks (241-AP-102 and -104).

The subset of DSTs that may contribute to "Tank T" are as follows:

Envelope A: 241-AN-103, 241-AN-104, 241-AN-105, 241-AW-101, 241-AW-104 Envelope B: $241-A Z-101,241-A Z-102$

Envelope C: $\quad$ 241-AN-102, 241-AN-107, 241-AN-106, 241-SY-101, 241-SY-103

\subsection{DEVELOP A DECISION RULE}

The decision rule for confirming that a source tank is appropriate for a specific batch is as follows:

1. IF the requirements in Sections 4.1 [ [Dilution Ratio and Diluent Composition Requirements are Satisfied] AND 4.2 [Transfer Requirements are Satisfied] AND 4.3 [Mixing Requirements are Satisfied] AND 4.4 [Envelope and Quantity Requirements are Satisfied] AND 4.5 [Miscellaneous Inputs are Satisfied] \}THEN the waste in the source tank is appropriate for a specific batch.

2. If the waste does not pass Decision Rule 1, then the technical staff will assess alternatives to meeting minimum order quantities, including other tank waste sources, dilution, blending, or other processes that can be used to generate a waste feed that meets the source tank waste criteria. RL may also elect to renegotiate the LAW feed specifications or other contract terms with the private contractor(s).

The elements of the decision rule (the terms in the [Brackets]) will be applied to the different scenarios developed by the Tank Waste Retrieval Division for each specific Tank T and Batch $\mathrm{X}$ combination. This provides the flexibility to account for unique factors that may only become apparent during the application of the DQO and to take advantage of existing data whenever possible.

It is anticipated that the TWRS Operation and Utilization Plan (TWRSO\&UP) (Kirkbride et al. 1997) will be updated and this DQO process revisited as new process information is . received, as contracts are amended, and as integrated process/product team needs are better defined. 


\subsection{SPECIFY LIMITS ON DECISION ERROR}

\subsection{DILUTION RATIO AND DILUENT COMPOSITION REQUIREMENTS}

Prior data show the desired dilution ratio and diluent composition for problem-free transfers can span a significant dilution ratio and diluent composition range. Hence, measures of the desired dilution ratio and diluent composition do not require precision, as long as the process tests follow standard laboratory practices and the standard quality assurance procedures for such process testing.

\subsection{TRANSFER REQUIREMENTS}

The objective of the transfer requirements is to provide a qualitative indication that the waste is pumpable. Parameters higher than 80 percent of the maximum allowable value are considered "flagged" for further examination.

\subsection{MIXING REQUIREMENTS}

These tests are intended to be a qualitative indication that the waste will dissolve reasonably fast and any undissolved solids are "settleable." 'Qualitative here means dissolving and settling are much faster than the time allotted ( 30 days) for processing (e.g., dissolving in minutes versus days allotted).

\subsection{ENVELOPE AND QUANTITY REQULREMENTS}

The objective is to make sure the waste composition in the tank is close enough to the required envelope composition so the staged waste will fit the envelope either as-is or with . blending and shimming.

Where point estimates of the waste composition are used: analytes which do not satisfy the envelope requirements or approach within 20 percent of an envelope requirement are considered "flagged" for further examination. Both the Waste Disposal Integration Team (WIT) and PHMC have been using the 20 percent value to identify potential problems in either defining or meeting envelope specifications. This estimate allows for typical sampling and analytical error and allows for a reasonable level of blending and/or shimming, if required.

Where best-basis inventory data can be used directly or as a bounding case, existing tank characterization data used to establish the best-basis inventory data should be evaluated statistically. Appropriate analysis of variance (ANOVA) models should be used to estimate the one-sided 95 percent confidence intervals above the mean for each analyte: sodium ratio. 
Components which fall outside of the envelope requirements or are missing are considered "flagged" for further examination.

For volume percent solids in a batch of feed: Values higher than 80 percent of the maximum allowable value are considered "flagged" for further examination.

For the amount of $\mathrm{Na}$ in a batch: a value of less than 120 percent of minimum required masses or outside $+/-20$ percent of the target masses (Table 4-5) are considered "flagged" for further examination.

\subsection{MISCELLANEOUS REQUIREMENTS}

The objective of these requirements is to assure that any additional elements (that may determine the waste in source tank is appropriate for a batch) are considered and resolved. Because of the nature of these requirements, a yes or no determination is usually adequate. If more quantification is required, it will be covered in the application of this DQO.

\subsection{DATA REPORTING}

\subsubsection{Laboratory Assessment and Report}

While it is imperative to produce all data following approved procedures, these are unique materials and some modifications to standard operating procedures may be required to generate technically valid analytical data (such as ${ }^{99} \mathrm{Tc}$ ). If such modifications are necessary, they must be clearly documented following the required protocols.

The data report shall show the precision and accuracy of the data. All analytes requiring reruns are to be explained in the case narrative. All raw data supporting such reruns shall be archived and available for review.

All analytical and supporting quality assurance/quality control (QA/QC) results will undergo a one-over-one technical review prior to the data report being issued to the Tank Waste Retrieval Division. An independent data validation (an administrative review of laboratory documents conducted for supporting regulatory compliance requirements) is not required for data developed under this DQO. 


\subsubsection{Dissolution/Dilution Testing and Report}

All testing will follow the Process Chemistry \& Statistics Quality Assurance Plan, WHC-SD-CP-QAPP-018, Rev. 0 (Meznarich 1996). Laboratory tests to determine the amount and type of dilution required for safe and efficient retrieval of the tank waste are based on test requirements established by Process Development (Garfield 1997).

Before testing, a test plan will be prepared and issued as a supporting document. After testing, the dissolved/diluted solids will be analyzed for most of the constituents in Table 4-7 and others determined in the test plan such as viscosity and settling rate. A complete report of the test results will be issued in the form of a supporting document.

\subsubsection{Data Quality Objective Assessment and Report}

The results of applying this DQO to a specific batch will be documented in a supporting document (Jo 1998) and will become the technical direction needed by TWRS Characterization and the organization performing the process test, if any. If there are unsatisfied information needs, TWRS Characterization will prepare a Tank Sampling and Analysis Plan (TSAP) or a letter of instruction in lieu of a TSAP.

\subsection{OPTIMIŻE THE DESIGN FOR OBTAINING DATA}

A minimum of five grab samples from one riser are recommended for Tank $T$ requiring supernate only. If the tank waste is core sampled, a full core is required from one riser to make a composite sample. All of the dilution/dissolution tests will begin with a whole-tank composite sample prepared from the five grab samples. The composite will be analyzed for the constituent in table 4-7 and be subjected to dissolution/dilution testing per the specific test plan described in section 7.6.2. Optimization of the design for obtaining the data, if any, will take place during the preparation of a sampling and analysis plan or process test plan. If valid assay data exist from prior sampling efforts, replication of those assays need not be done for the source tank characterization. 


\subsection{REFERENCES}

Banning, D. L., 1997, TWRS Administrative Manual, HNF-IP-0842, Volume IV, "Engineering," Section 4.16, Rev. 0, "Data Quality Objectives for Sampling and Analyses," Lockheed Martin Hanford Corporation, Richland, Washington.

DOE-RL, 1996, U.S. Department of Energy Contract DE-AC06-RL13308, dated September 25, 1996 and Contract DE-AC-RL11309 dated September 25, 1996, U.S. Department of Energy, Richland Operations Office, Richland, Washington.

Galbraith, J. D., T. B. Salzano, and J. R. Nicholson, 1996, Decision Document for Phase I Privatization Transfer System Needs, WHC-SD-WM-TI-750, Rev. 0., Westinghouse Hanford Company, Richland, Washington.

Garfield, J. S., 1997, Tank 241-AN-105 Dilution/Dissolution Test Requirement, Internal Memo 8C451-97-004, Numatec Hanford Corporation, Richland, Washington.

Jo, J., 1998, Application of "Confirm Tank T is an Appropriate Feed Source for Low-Activity Waste Feed Batch X" to Specific Feed Batches, HNF-2799, Rev. 0 (to be issued), Lockheed Martin Hanford Corporation, Richland, Washington.

Kirkbride, R. A., G. K. Allen, P. J. Certa, A. F. Manuel, R. M. Orme, L. W. Shelton, E. J. Slaathaug, R. S. Wittman, G. T. MacLean, and D. L. Penwell, 1997, Tank Waste Remediation System Operation and Utilization Plan, HNF-SD-WM-SP-012, Rev. 0A, Vol. I and II, Numatec Hanford Corporation, Richland, Washington.

Meznarich, H. K., 1996, Process Chemistry \& Statistics Quality Assurance Plan, WHC-SD-CP-QAPP-018, Rev. 0, Westinghouse Hanford Company, Richland, Washington.

Mulkey, C. H., 1997, Data Quality Objectives for Tank Farms Waste Compatibility Program, HNF-SD-WM-DQO-001, Rev. 2, Lockheed Martin Hanford Corporation, Richland, Washington.

Papp, I. G., 1998, Process Development Work Plan for Waste Feed Delivery System, HNF-2403, Rev, 0, Numatec Hanford Corporation, Richland, Washington.

Payne, M. A., J. O. Honeyman, J. G. Kristofzski, W. T. Thompson, and P. J. Certa, 1998, Management Assessment of Tank Waste Remediation System Contractor Readiness to Proceed with Phase $1 B$ Privatization, HNF-2021, Rev. 1, Lockheed Martin Hanford Corporation, Richland, Washington. 
PHMC, 1997a, Interface Control Document Between DOE and the PHMC, Low Activity Waste Feed, HNF-SP-1223 (ICD-19), Project Hanford Management Contract, Richland, Washington.

PHMC, 1997b, Unclassified Operating Specification for the 241-AN, AP, AW, AY, AZ, and SY Tank Farms, OSD-T-151-00007, Rev. H, Fluor Daniel Hanford, Richland, Washington.

WHC, 1996, TWRS Administration, "Decision Management," WHC-IP-0842, Volume IV, Section 2.7, Rev. 0A, Westinghouse Hanford Company, Richland, Washington. 
This page intentionally left blank. 


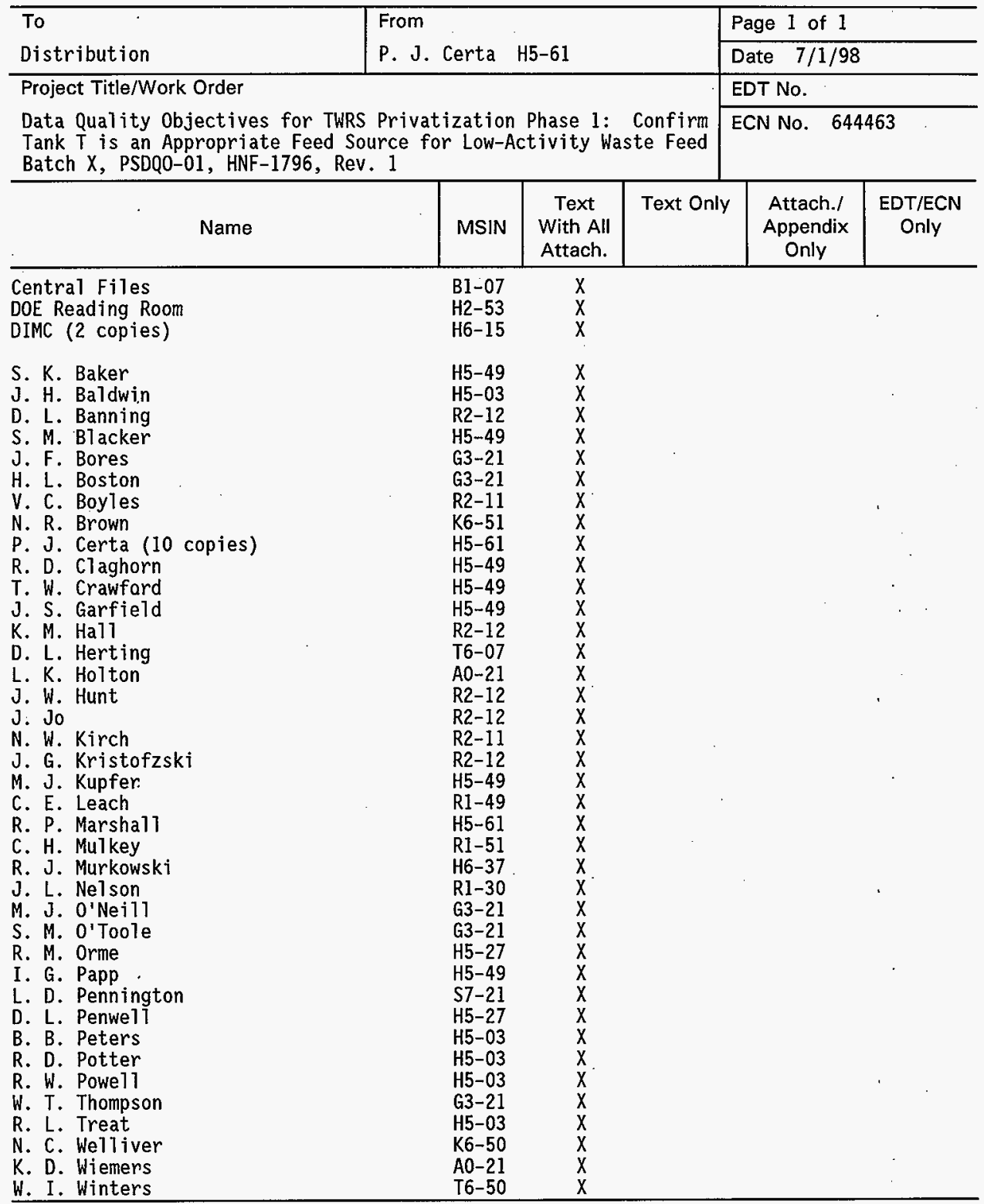

